Saudi Journal of Medicine

Abbreviated Key Title: Saudi J Med ISSN 2518-3389 (Print) |ISSN 2518-3397 (Online)

\title{
A Study of Serum Concentration of Vitamin D in Patients Suffering with Tuberculosis:
}

\author{
Dr. Krishna Prasad R ${ }^{1}$, Dr. Shreesha Khandige ${ }^{2 *}$ \\ ${ }^{1}$ Associate Professor, Department of TB and Chest (Respiratory Medicine), Kanachur Institute of Medical Sciences, Deralakatte, Mangalore. \\ ${ }^{2}$ Professor and HOD, Department of Pathology, Kanachur Institute of Medical Sciences, Deralakatte, Mangalore India
}

DOI: $10.36348 /$ sjm.2020.v05i02.008 $\quad$ | Received: 03.02.2020 | Accepted: 10.02 .2020 | Published: 14.02 .2020

*Corresponding author: Dr. Shreesha Khandige

\section{Abstract}

Tuberculosis is one of the dreaded infections which are commonly found in our country. In fact there is a saying that if none of the medicines wok and the patients is still ill then there is a high chance of the patient suffering from tuberculosis in India. Vitamin D has been observed to be low and has been always understood to have an influence in the patient's outcome also. There is no base line study done to understand the involvement of the Vit D in the patients. So this study is one such novel effort to understand the same.

Keywords: Tuberculosis, Incidence, Vitamin D, Serum Levels.

Copyright @ 2020: This is an open-access article distributed under the terms of the Creative Commons Attribution license which permits unrestricted use, distribution, and reproduction in any medium for non-commercial use (NonCommercial, or CC-BY-NC) provided the original author and source are credited.

\section{INTRODUCTION}

Tuberculosis is one of the dreaded infections which is commonly found in our country. In fact there is a saying that if none of the medicines wok and the patients is still ill then there is a high chance of the patient suffering from tuberculosis in India. Vitamin D has been observed to be low and has been always understood to have an influence in the patient's outcome also.

About one-third of the world population is infected with Mycobacterium tuberculosis, but only one-tenth of them show clinical symptoms. It is compared with HIV in mortality rate in the world [1]. In spite of the fact that new drugs were developed in the last sixty years; controlling TB is still a big challenge. Using multiple antibiotics could potentially create problems such as drug resistance, expensive treatments and side effects [2]. Which encourage researchers to search for alternative remedies or use other auxiliary factors in the acceleration of treatment process to decrease drug resistance rates? In this field, the role of vitamin $\mathrm{D}$ is one of the most important factors in promoting host immune system [3] which has drawn the researchers' attention. The possibility of drug resistance in TB patients is very high because of the plurality of prescribed drugs (Rifampicin, Isoniazid, Pyrazinamide, and Ethambutol), long treatment period (at least six months) or stopping treatment [4]. The active form of vitamin $\mathrm{D}(1,25(\mathrm{OH}) 2$ vitamin $\mathrm{D} 3)$ inhibits the intracellular growth of the bacteria, through inducing production of the antimicrobial peptide, cathelicidin, and helps to the autophagy of macrophages which have been contaminated with M. tuberculosis [5]. According to in vitro evidence, the active form of the vitamin $D$ inhibits the bacteria replication within macrophages by stimulating the immune system $[6,7]$.

There is no base line study done to understand the involvement of the Vit D in the patients. So this study is one such novel effort to understand the same.

\section{AIMS AND OBJECTIVES}

Serum concentration correlation study with the severity of the disease Case and control correlation of Vitamin D.

\section{MATERIALS AND METHODS}

This study was done in the Department of Respiratory Medicine with collaboration with the Department of Pathology.

Seventy TB patients were matched for sex and age with ninety controls and then the serum was tested for the levels of Vitamin D levels.

2019.

The study was done from May 2018 to April

Statistical analysis were done to evaluate the levels of Vitamin D serum levels and to check the association. 


\section{RESULTS}

Table-1: Table 1: Age Distribution

\begin{tabular}{|l|l|l|l|}
\hline Group & Number & Mean age & Std Deviation \\
\hline Case & 70 & 42.73 years & 4.48 years \\
\hline Control & 90 & 35.83 years & 3.73 years \\
\hline
\end{tabular}

Table-2: Seum Vit D Levels

\begin{tabular}{|l|l|l|l|}
\hline Parameter & Case & Control & p-value \\
\hline $25-(\mathrm{OH}) \mathrm{D}(\mathrm{ng} / \mathrm{ml})$ & $11.27 \pm 2.98$ & $25.02 \pm 1.36$ & $<0.05$ \\
\hline
\end{tabular}

\section{DISCUSSION}

It is considered that there is a two way connection between plasma level of vitamin $\mathrm{D}$ and tuberculosis, This means that anti-TB drugs, such as isoniazid and rifampicin used in the treatment of TB, reduce the level of this vitamin in blood through various kind of mechanisms and reduction of this vitamin in blood along with the immune system suppression results in intensification of the disease. The study on cultured THP-1 cells revealed that adding anti-TB drugs significantly reduced the expression of cathelicidin mRNA, which calcitriol was its trigger in treated macrophages. In addition, clinical studies on patients with TB who used 4 anti-TB standard drugs showed that there was a high prevalence of vitamin D deficiency in these patients. Two major first-line drugs in the treatment of TB, isoniazid, and rifampin, and their influence on the content of vitamin $\mathrm{D}$ have been investigated. Isoniazid acts as an inhibitor of CYP450 and reduces both of vitamin $\mathrm{D}$ hydroxylation phases. This results in the reduction of the concentration of 25hydroxyvitamin D and 1, 25-dihydroxyvitamin D. Rifampicin is a strong inducer of CYP3A4 which is a 24,25-hydroxylase of vitamin $\mathrm{D}$ and its activation results in inactivation of 25-hydroxyvitamin D. However, the results also show that the concentrations of serum 25-hydroxyvitamin D during the first two months of treatment by anti-tuberculosis drugs have increased which is attributed to the improvement of patient's food diet due to the significant clinical improvement of patients in the first weeks of treatment. Another possible mechanism is the decrease of inflammatory stimuli during the process of starting of TB treatment, so 25-hydroxyvitamin D is less hydroxylated and serum level of this vitamin has increased [8-10]. It seems that the assessment of serum level of the vitamin $\mathrm{D}$ in $\mathrm{TB}$ patients at the first and also during the treatment process is essential.

\section{CONCLUSION}

There is a significance difference between the Vitamin D levels that has been observed between the case and the control.

\section{REFERENCES}

1. Zumla, A. (2015). "The WHO 2014 global tuberculosis report--further to go". Lancet Global Health, 3(1): e10-e12.
2. Rashedi, J. (2015). "Multidrug-resistant tuberculosis in north-west of Iran and Republic of Azerbaijan: a major public health concern for Iranian people". Journal of Research in Health Sciences, 15(2): 101-103.

3. Rashedi, J. (2014). "Vitamin d receptor gene polymorphism and vitamin d plasma concentration: correlation with susceptibility to tuberculosis". Advanced Pharmaceutical Bulletin, 4(2), 607-611.

4. Sis, H. Y., Rashedi, J., Azabdaftari, F., Poor, B. M., Asgharzadeh, M., Jannati, A., \& Jafarabadi, M. A. (2015). An innovative method to enhance the modified DOTS for TB patients. Tanaffos, 14(3), 177.

5. Liu, P. T., Stenger, S., Tang, D. H., \& Modlin, R. L. (2007). Cutting edge: vitamin D-mediated human antimicrobial activity against Mycobacterium tuberculosis is dependent on the induction of cathelicidin. The journal of immunology, 179(4), 2060-2063.

6. Selvaraj, P. (2015). "Vitamin D: Immunomodulation and tuberculosis treatment". Canadian Journal of Physiology and Pharmacology, 93(5): 377-384.

7. Lewis, S.J., B.I., \& Davey, S.G.(2005). "Metaanalysis of vitamin D receptor polymorphisms and pulmonary tuberculosis risk". International Journal of Tuberculosis and Lung Disease, 9(10), 11741177.

8. Pourostadi, M., Rashedi, J., Poor, B. M., Kafil, H. S., Shirazi, S., \& Asgharzadeh, M. (2016). Molecular Diversity of Mycobacterium tuberculosis Strains in Northwestern Iran. Jundishapur journal of microbiology, 9(9).

9. Lönnroth, K., Jaramillo, E., Williams, B. G., Dye, C., \& Raviglione, M. (2009). Drivers of tuberculosis epidemics: the role of risk factors and social determinants. Social science \& medicine, 68(12), 2240-2246.

10. Leandro, A. C. C. S., Rocha, M. A., Cardoso, C. S. A., \& Bonecini-Almeida, M. G. (2009). Genetic polymorphisms in vitamin $\mathrm{D}$ receptor, vitamin $\mathrm{D}$ binding protein, Toll-like receptor 2 , nitric oxide synthase 2, and interferon- $\gamma$ genes and its association with susceptibility to tuberculosis. Brazilian Journal of Medical and Biological Research, 42(4), 312-322. 